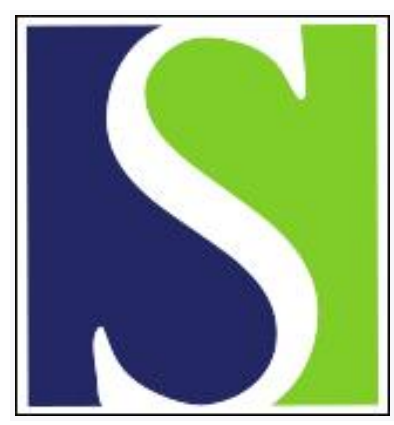

Scand J Work Environ Health 1996;22(3):211-215

https://doi.org/10.5271/sjweh.133

Issue date: Jun 1996

Exercise testing of young, apparently healthy professional drivers

by Uglješic $M$, Belkic $K$, Boškovic $D$, Boškovic $S$, llic $M$

Key terms: cardiovascular disease; exercise testing; professional driver

This article in PubMed: www.ncbi.nlm.nih.gov/pubmed/8837267

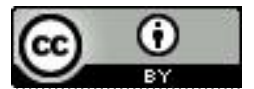




\title{
Exercise testing of young, apparently healthy professional drivers
}

\author{
by Mirjana Uglješić, MD, ${ }^{1}$ Karen Belkić, MD, ${ }^{1,3}$ Dejan Bošković, MD, Snežana Bošković, MD, ${ }^{4}$ \\ Mirka llić, MSC ${ }^{3}$
}

\begin{abstract}
Uglješić M, Belkić K, Bošković D, Bošković S, Ilić M. Exercise testing of young, apparently healthy professional drivers. Scand J Work Environ Health 1996;22:211- 15.

Objective The purpose of this study was to examine the responses of young, apparently healthy professional drivers to exercise testing.

Methods A bicycle exercise test was performed by a randomly selected group of 42 apparently healthy, male professional drivers aged 20 to 40 years and a group of 30 building workers, who formed a reference group.

Results The mean maximal exercise level was significantly lower for the drivers [139 (SD 32) W] than for the referents [155 (SD 31) W] $(\mathrm{P}<0.05)$. The mean systolic blood pressure and heart rate did not differ significantly between the groups at the end of the exercise, but the mean double product was significantly higher for the drivers. The mean diastolic blood pressure at the end of the exercise was 97 (SD 14) $\mathrm{mm} \mathrm{Hg}$ [12.9 (SD 11.9) $\mathrm{kPa}]$ for the drivers and 79 (SD 19) $[10.5(\mathrm{SD} 2.5) \mathrm{kPa}]$ for the referents $(\mathrm{P}<0.01)$. The exercise was stopped due to diastolic hypertensive reactions [diastolic blood pressure $>115 \mathrm{~mm} \mathrm{Hg}(>15.3 \mathrm{kPa})$ ] in $13(31 \%)$ of the drivers and $3(10 \%)$ of the referents $(\mathrm{P}<0.05)$. Eight of the thirteen drivers with a hypertensive reaction had three or more cardiac risk factors.

Conclusions There seems to be a high occurrence of diastolic hypertensive reactions to exercise among professional drivers. These reactions may be associated with risk of ischemic heart disease and hypertension. Further exercise testing of professional drivers is warranted. More sensitive methods may be indicated in selected cases, since the cardiovascular status of this cohort is a vital concern with respect to traffic safety.
\end{abstract}

Key terms cardiovascular disease, exercise testing, professional drivers.

Recent reviews of the medical literature have consolidated evidence which strongly demonstrates that professional drivers belong to an occupational group at high risk of developing hypertension, myocardial infarction, and other forms of ischemic heart disease. The risk is, at least in part, stress-related and begins at an unusually young age $(1,2)$. These findings are of particular importance because of their potential implications with regard to traffic safety. Hlatky (3) has emphasized that exercise stress testing to screen for coronary artery disease in asymptomatic persons can be justified for occupational categories such as drivers insofar as sudden incapacitation could endanger others. Such an approach has been taken for sea pilots and captains, other high stress occupations also found to have excess risk of ischemic heart disease in epidemiologic studies $(4,5)$ and for whom exercise testing has revealed a significantly greater prev- alence of pathological electrocardiograms when compared with matched men in the Oslo population $(6,7)$.

To our knowledge, there are no published studies in which professional drivers have been systematically examined with ergometry. The objective of this study was to apply exercise testing in a group of young, apparently healthy male professional drivers and a matched group from the working population, and to view the results in relation to standard risk factor status for ischemic heart disease.

\section{Subjects and methods}

\section{Subjects}

The subjects were randomly selected from individuals seen at the Ambulatory Occupational Health Center in

1 Ambulatory Occupational Health Center, Belgrade, Yugoslavia.

2 Institute for Psychosocial Factors in Medicine, Stockholm, Sweden.

3 University Clinical Center, Belgrade, Yugoslavia.

4 Cardiology Clinic, Čačak, Yugoslavia.

Reprint requests to: Dr Karen Belkić, National Institute for Psychosocial Factors in Medicine, PO Box 230, Karolinska Institute, S-171 77 Stockholm, Sweden. 
Belgrade, Yugoslavia, during 1990 to 1991 . They were undergoing periodic medical examinations which are provided to all employees of a given enterprise, regardless of the presence or absence of medical complaints or diagnoses. The Center primarily serves professional drivers, craftsmen, and other individuals employed in construction trades. All actively working city mass transit and truck drivers from a large number of local firms underwent systematic preventive examinations on a triannual basis. Building trade workers who worked on heights were seen annually.

The selection criteria were (i) male, employed in current profession for at least five years, and aged 40 years or less, (ii) no recent illness and no use of medication, (iii) no history of organic heart disease and no complaints of chest pain or other symptoms suggestive of ischemic heart disease, (iv) normal cardiopulmonary examination and resting electrocardiogram and resting blood pressure no greater than $140 / 90 \mathrm{~mm} \mathrm{Hg}(18.6 / 12 \mathrm{kPa})$.

Persons who fulfilled these criteria were informed that they could choose to participate in additional testing with the aim of cardiovascular disease prevention for apparently healthy workers in strenuous or stressful occupations. They were told that this procedure entailed exercise testing and completion of a short questionnaire and laboratory analysis and that the results would remain confidential and would not affect their professional status. They were also told that they were free to withdraw from the protocol at any time without any consequences whatsoever.

The prevalence of resting electrocardiographic changes and complaints of chest pain and other symptoms suggestive of ischemic heart disease were less than $1 \%$ among these working populations. The major reason for noninclusion in the study was blood pressure over $140 / 90 \mathrm{~mm} \mathrm{Hg}(18.6 / 12 \mathrm{kPa})$, which was found for about $15 \%$ of the professional drivers and $10 \%$ of the referents.

Altogether, 72 workers who fulfilled the inclusion criteria were randomly chosen to be part of the study. All of these subjects agreed to participate; there were 42 professional drivers with a mean age of 33.9 years and 30 referents (physical workers in the building trades or milling or baking industry (mean age 32.6 years). All of the subjects underwent exercise testing and completed the questionnaire. Blood samples were taken on a separate occasion and analyzed at the University Clinical Center in Belgrade. A total of 27 of the $42(64.3 \%)$ drivers and 25 of the $30(83.3 \%)$ referents provided a blood sample for the laboratory testing.

The professional drivers and referents had the following standard cardiac risk factor profile, analyzed dichotomously. Twenty-six (62\%) professional drivers and fifteen $(50 \%)$ of the referents were current smokers of 20 or more cigarettes a day and had been smoking for over five years. A body mass index greater than 28 was found for $16(38 \%)$ professional drivers and $14(47 \%)$ referents. A total of 16 professional drivers $(38 \%)$ and 13 $(43 \%)$ referents were sedentary during leisure time, defined as less than $2 \mathrm{~h}$ of recreational physical activity per week.

No cases of hyperglycemia (fasting levels of serum glucose $>6.7 \mathrm{mmol} \cdot 1^{-1}$ ) were registered among the 27 drivers and 25 referents who provided a blood sample. Hypercholesterolemia (fasting low-density lipoprotein cholesterol $>4.53 \mathrm{mmol} \cdot \mathrm{l}^{-1}$ ) was found for 17 $(63 \%)$ drivers and $14(56 \%)$ referents. A total of 14 $(52 \%)$ drivers who gave a blood sample and 7 (28\%) referents had hypertriglyceridemia (fasting triglycerides $>1.9 \mathrm{mmol} \cdot \mathrm{I}^{-1}$ ). The given laboratory values represent the upper limit of normal for the University Clinical Center.

\section{Exercise protocol}

Exercise testing was performed at the Ambulatory Occupational Health Center in Belgrade, usually on the same day as the periodic systematic examination, on a bicycle ergometer with the subject in a sitting position. The initial work load was set at $50 \mathrm{~W}$, and it was incrementally augmented by $30 \mathrm{~W}$ every $3 \mathrm{~min}$.

Bipolar lead CM5 was recorded continuously during the exercise and for 7 min thereafter. A 12-lead electrocardiogram was recorded at minute 2 of each exercise level, as well as during minutes $1,3,5$ and 7 of the subsequent resting period. Deviations of the ST segment were assessed $0.08 \mathrm{~s}$ after the "J" point. Blood pressure was measured by auscultation over the brachial artery, using an aneroid sphygmomanometer at minute 2 of each exercise level, as well as during the previously mentioned intervals at rest.

Exercise was terminated for the following reasons: (i) at the request of the subject due to chest pain, severe dyspnea or extreme fatigue, (ii) marked hypertensive reaction [systolic blood pressure $>220 \mathrm{~mm} \mathrm{Hg}(29.3$ $\mathrm{kPa}$ ) or diastolic blood pressure $>115 \mathrm{~mm} \mathrm{Hg}(15.3 \mathrm{kPa})]$, (iii) systolic hypotension [a fall in systolic blood pressure of $>20 \mathrm{~mm} \mathrm{Hg}(>2.7 \mathrm{kPa}$ ) during exercise, (iv) depression of the ST segment exceeding $2 \mathrm{~mm}$ or complex ventricular arrhythmias.

All the exercise tests were performed on a nonwork day, from 0900 to 1300 , with at least two elapsed hours from the time the subject last smoked a cigarette or drank coffee or other caffeinated beverages. All the subjects had slept normally the previous evening (no night shift work) and had eaten a light breakfast after which at least 2 to $3 \mathrm{~h}$ had passed before the test was begun.

\section{Statistical methods}

A chi-square test was used for the discrete variables, and a two-tailed, two-sample "t" test was applied for the continuous variables. 
Table 1. Heart rate and blood pressure responses at the maximum exercise level attained by the professional drivers and building worker referents.

\begin{tabular}{|c|c|c|c|c|c|c|c|c|c|c|}
\hline & \multicolumn{2}{|c|}{$\begin{array}{c}\text { Maximum exercise } \\
\text { level } \\
\text { (N) }\end{array}$} & \multicolumn{2}{|c|}{$\begin{array}{c}\text { Heart rate } \\
\left(\text { beats } \cdot \text { min }^{-1}\right)\end{array}$} & \multicolumn{2}{|c|}{$\begin{array}{l}\text { Systolic blood } \\
\text { pressure } \\
(\mathrm{mm} \mathrm{Hg})\end{array}$} & \multicolumn{2}{|c|}{ Double product } & \multicolumn{2}{|c|}{$\begin{array}{c}\text { Diastolic } \\
\text { blood pressure } \\
\left.(\mathrm{mm} \mathrm{Hg})^{2}\right)\end{array}$} \\
\hline & Mean & $\mathrm{SD}$ & Mean & SD & Mean & SD & Mean & SD & Mean & SD \\
\hline Professional drivers $(N=42)$ & $139^{*}$ & 32 & 170 & 18 & 200 & 20 & $34025^{*}$ & 5273 & $97^{* *}$ & 14 \\
\hline Referents $(N=30)$ & 155 & 31 & 165 & 15 & 192 & 19 & 31672 & 3945 & 79 & 19 \\
\hline
\end{tabular}

a $\mathrm{mm} \mathrm{Hg} \approx 0.133 \mathrm{kPa}$.

* $P<0.05,{ }^{* *} P<0.01$ (two-sample " $\mathrm{t}$ " test).

\section{Results}

Table 1 reveals that the maximum exercise level attained was significantly lower for the professional drivers than for the referents. The two groups did not differ significantly with respect to systolic blood pressure or heart rate levels recorded at the end of exercise. The double product was, however, significantly greater $(\mathrm{P}<0.05)$ for the professional drivers [34025 (SD 5273)] than for the referents [31672 SD 3945)]. The diastolic blood pressure recorded at the end of exercise was also significantly higher $(\mathrm{P}<0.01)$ for the professional drivers [97 (SD 14) $\mathrm{mm} \mathrm{Hg} ; 13.0(\mathrm{SD} 1.9) \mathrm{kPa}$ ] than for the referents [79 (SD 19) $\mathrm{mm} \mathrm{Hg}$; 10.5 (SD 2.5) $\mathrm{kPa}$. Furthermore, as shown in figure 1 , there was a significantly larger $(\mathrm{P}<0.05)$ number of frankly hypertensive diastolic blood pressure responses (diastolic blood pressure $>115 \mathrm{~mm}$ $\mathrm{Hg} ;>15.3 \mathrm{kPa}$ ) among the professional drivers $(\mathrm{N}=13$ or $31 \%)$ than among the referents $(\mathrm{N}=3$ or $10 \%)$. There were systolic hypertensive responses to exercise in five of the drivers and in one referent (nonsignificant difference).

Of the 13 drivers with a diastolic hypertensive reaction to exercise, seven (54\%) were current smokers, four (31\%) were obese, and twelve $(92 \%)$ were sedentary in their leisure time. Only nine of the 13 underwent laboratory testing. Of these, five (56\%) had hypercholesterolemia and six (67\%) had triglyceridemia. According to the available data, 8 of the 13 drivers with a hypertensive reaction had at least three standard risk factors present. One of the three referents with a hypertensive reaction had three risk factors (obesity, sedentary leisure time and hypertriglyceridemia), whereas the other two had no discernable standard risk factors for cardiac disease.

\section{Discussion}

The professional drivers attained a significantly lower maximum exercise level when compared with the referents, but with a significantly higher double product, suggesting a lower level of physical fitness among the

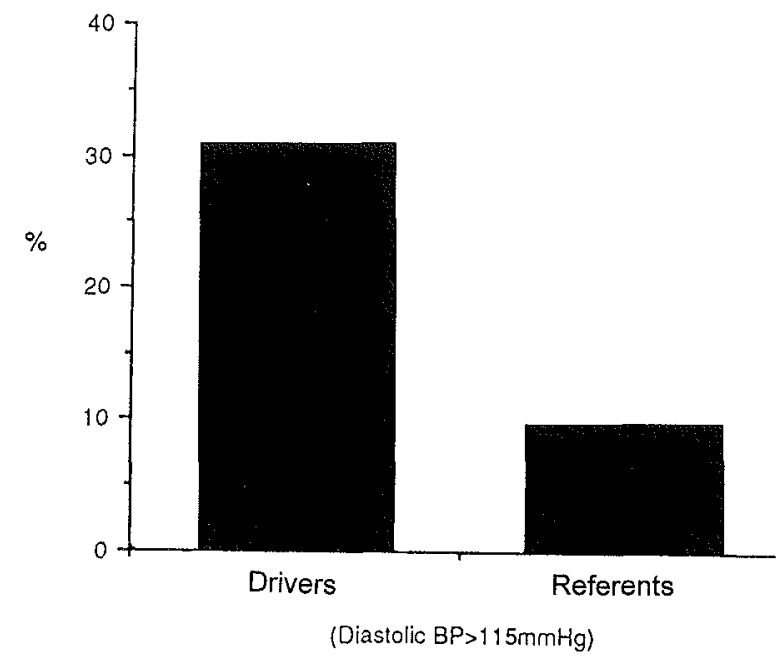

Figure 1. Frankly hypertensive diastolic responses to exercise [diastolic blood pressure $(\mathrm{BP})>115 \mathrm{~mm} \mathrm{Hg}, 15.3 \mathrm{kPa}$ a among the resting normotensive professional drivers and building worker referents.

former. Since the two groups did not differ significantly with respect to leisure-time sedentariness, it is possible that the lack of workplace physical activity among the drivers, when compared with the referents, may have affected the fitness levels. Hedberg and her colleagues (8) found that professional drivers had a significantly higher level of sedentary occupational activity than referents in the Monica study. On the basis of a 16-year follow-up of healthy, middle-aged men, Sandvik and his colleagues (9) have recently reported that poor physical fitness is an independent risk factor for cardiovascular mortality.

The most striking finding in this study was that, compared with the referents, the professional drivers had significantly higher diastolic blood pressure at the end of exercise, together with a significantly greater number of diastolic hypertensive reactions. Diastolic blood pressure normally remains unchanged, or drops slightly, during exercise $(10,11)$. A rise in diastolic blood pressure with exercise may be an early indicator of hypertension (10), to which professional drivers are prone (12-19).

Akhras and his colleagues $(20,21)$, on the basis of their invasive investigations of coronary patients, have suggested that a marked rise in diastolic blood pressure 
in response to exercise could identify persons at high risk of ischemic heart disease, but with otherwise negative exercise tests. According to these authors, exercise-induced ischemia may lead to a reversible fall in cardiac output, which can also cause reflex vasoconstriction and increased diastolic blood pressure, but without a drop in systolic blood pressure or ST segment changes. Corroborative data have been provided by Ironson and her colleagues (22), who have reported that healthy referents had a slight fall in diastolic blood pressure, whereas patients with coronary heart disease showed a rise in diastolic blood pressure with bicycle exercise testing.

The drivers with a diastolic hypertensive reaction to exercise also had a markedly positive standard cardiac risk factor profile. Considering the recognized tendency for professional drivers to deny symptoms $(16,23)$, and their high risk status as a profession, further diagnostic work-up may be warranted for persons in this occupational group who show a frankly diastolic hypertensive response to exercise.

Apparently healthy, young professional drivers have been reported to show a diastolic hypertensive reaction to a laboratory procedure which mimics the cognitively relevant sensory stress of their work environment (the Glare Pressor Test) $(24,25)$. This reaction is of less magnitude, however, than that to exercise. They also showed a significantly higher diastolic, as well as systolic, blood pressure response during work, compared with that of clerical worker referents (26).

Manuck (27) very recently reviewed the literature and found that diastolic hyperactivity to mental stress testing and augmented blood pressure during occupational activities are associated with an increased left ventricular mass, which has been recognized as an independent risk factor for cardiovascular morbidity and mortality. Among hyperreactive patients with coronary artery disease, a significant positive correlation can be found between diastolic blood pressure levels measured during mental stress and during upright bicycle exercise [correlation coefficient $=0.636, \mathrm{P}<0.05$, as calculated from the raw data presented by Schiffer et al (28)].

Driving has been consistently demonstrated to elicit elevations in catecholamine excretion (29-32). The findings presented in this paper, together with those reported previously, suggest that professional drivers show a diastolic hyperresponsiveness both to exercise and to work-related stressors. The common denominator may be hypersecretion of norepinephrine, which, in turn, is associated, among other things, with left ventricular hypertrophy (27). Catecholamine hypersecretion in response to environmental stimuli is also characteristic of the metabolic cardiovascular syndrome (33).

A fruitful avenue for future study among this cohort would therefore be further systematic investigation using exercise stress testing, together with an evaluation of cardiovascular reactivity to laboratory tests which mimic aspects of their work environment, ideally with catecholamines measured in relation to these procedures. The assessment of left ventricular mass and further evaluation of atherogenic biochemical abnormalities would also be of great value for further untangling the mechanisms of cardiac risk among professional drivers. The results of such investigations would help us develop more effective early detection and prevention of these disorders among professional drivers.

\section{Acknowledgments}

This study was presented at the Meeting of the Working Group on Epidemiology and Prevention, European Society of Cardiology, Venice, April 1994, and printed as an extended abstract in Acta Cardiologica 1994;49:359-61.

Dr Belkic was supported as a guest researcher by grants from the Swedish Medical Research Council and the Swedish Work Environment Fund.

The authors would like to thank Dr Stella Cizinsky, Department of Cardiology, Thorax Clinic, Karolinska Hospital for her review of the manuscript and helpful suggestions.

\section{References}

1. Winkleby MA, Ragland DR, Fisher JM, Syme SL. Excess risk of sickness and disease in bus drivers: a review and synthesis of epidemiologic studies. Int J Epidemiol 1988;17:255—62.

2. Belkić K, Savić Č, Theorell T, Rakić L, Ercegovac D, Djordjević M. Mechanisms of cardiac risk among professional drivers. Scand J Work Environ Health 1994;20:73-86.

3. Hlatky MA. Exercise stress testing to screen for coronary artery disease in asymptomatic persons. J Occup Med 1986;28: $1021-5$.

4. Harrington JM. Mortality from coronary artery disease of English and Hamburg sea pilots. Trans Soc Occup Med 1972; 22:19-23.

5. Zorn EW, Harrington JM, Goethe H. Ischaemic heart disease and stress in West German sea pilots. J Occup Med 1977;19: $752-5$.

6. Mundal R, Erikssen J, Rodahl K. Latent ischemic heart disease in sea captains. Scand $\mathbf{J}$ Work Environ Health 1982;8: $178-84$.

7. Erikssen J, Johansen AH, Rodahl K. Coronary heart disease in Norwegian sea-pilots: part of the occupational hazard? Acta Med Scand Suppl 1981;645:79-83.

8. Hedberg GE, Jacobsson KA, Janlert U, Langendoen S. Risk indicators of ischemic heart disease among male professional drivers in Sweden. Scand J Work Environ Health 1993;19: $326-33$.

9. Sandvik L, Erikssen J, Thaulow E, Erikssen G, Mundal R, Rodahl $\mathrm{K}$. Physical fitness as a predictor of mortality among healthy, middle-aged Norwegian men. N Engl J Med 1993; $328: 533-7$. 
10. Kremser CB, Rajfer SI. The normal cardiovascular response to exercise. In: Leff AR, editor. Cardiopulmonary exercise testing. Orlando (FL): Grune \& Stratton, 1986:107-21.

11. Michelsen S, Otterstad JE. Blood pressure response during maximum exercise in apparently healthy men and women. J Int Med 1990;227:157-63.

12. Adum O, Djordjević M. Saobraćaj D. [Traffic]. In: Stanković, editor. Medicina Rada. Sarajevo: Dom Štampe Zenice, 1978: $858-62$.

13. Belgrade Inner-city Outpatient Services. Analiza zdravstvenog stanja radnika GSP-a [Analysis of the health status of employees of the Belgrade city bus company]. Belgrade Inner-city Outpatient Services, 1986. Izveštaj od Doma Zdravlja Stari Grad u Beogradu [Report from the Belgrade inner-city outpatient services].

14. Backman A-L. Health survey of professional drivers. Scand J Work Environ Health 1983;9:30-5.

15. Belkić K, Gluhak M, Ugljesíć M, Micković Lj, Sladić R. UCestalost abnormalnosti arterijskog krvnog pritiska i elektrokardiograma kod vozača gradskog saobraćajnog preduzeća Beograd [Prevalence of high blood pressure and electrocardiographic abnormalities among Belgrade mass transit drivers]. Revija Rada 1990;20:50—60.

16. Belkié K, Pavlović S, Djordjević M, Ugljesić M, Micković Lj. Determinants of cardiac risk in professional drivers. Kardiologija 1992;13:145-9.

17. Pikus WG, Tarranikova WA. The frequency of hypertensive disease among drivers in public transportation. Ter Arkh 1975; 47:135-7.

18. Ragland D, Winkleby MA, Schwalbe J, Holman BL, Morse L Syme SL, et al. Prevalence of hypertension in bus drivers. Int $J$ Epidemiol 1987;16:208-14.

19. Yokoyama E, Teru S, Mijake T, Mashita M, Tsuchihasi M, Ariga T, et al. Health care of truck drivers with reference to blood pressure control. Nihon Univ J Med 1985;27:225—38.

20. Akhras F, Jackson G. Raised exercise diastolic blood pressure as indicator of ischaemic left ventricular function. Lancet 1991;337:899-900.

21. Akhras F, Upward J, Jackson G. Increased diastolic blood pressure response to exercise testing when coronary artery disease is suspected: an indication of severity. Br Heart $\mathrm{J}$ 1985;53:598-602.

22. Ironson G, Taylor CB, Boltwood M, Bortzokis T, Dennis C, Chesney $M$, et al. Effects of anger on left ventricular ejection fraction in coronary artery disease. Am J Cardiol 1992;70:281-5.
23. Sladić-Marinković R. Analiza uzroka invalidnosti kod vozača autobusa Gradskog Saobracaja Beograd, invalida I, II i III kategorije u periodu 1980-1983 [Analysis of the causes of disability among Belgrade city mass transit drivers during 1980 to 1983] [dissertation]. Belgrade: University of Belgrade School of Medicine, 1986.

24. Belkić K, Micković Lj, Milić B, Savić S. Blood pressure and electrocardiographic changes elicited by the glare pressor test. Arch Environ Health 1987:42:37-43.

25. Belkić K, Ercegovac D, Slavić Č, Panić B, Djordjević M Savić $S$. EEG arousal and cardiovascular reactivity in professional drivers: the glare pressor test. Eur Heart J 1992;13: 304-9.

26. Uglješić M, Belkić K, Bơ̌ković S, Avramović D, Micković $\mathrm{Lj}$. Porast arterijskog krvnog pritiska tokom rada i profil rizika kod stresogenih profesija: novinari i vozači gradskog saobracaja [Increased arterial blood pressure during work and risk profile among high-stress occupations: journalists and city mass transit drivers]. Kardiologija 1992;13:150—4.

27. Manuck SB. Cardiovascular reactivity in cardiovascular disease: "once more unto the breach". Int J Behav Med 1994;1:4-31.

28. Schiffer F, Hartley LH, Schulman CL, Abelmann WH. Evidence for emotionally-induced coronary arterial spasm in patients with angina pectoris. Br Heart J 1980;44:62-6.

29. Bellet S, Roman L, Kostic J. The effect of automobile driving on catecholamine and adrenocorticosteroid excretion. Am J Cardiol 1969;24:365—8.

30. Evans GW, Carrere $S$. Traffic congestion, perceived control and psychophysiologic stress among urban bus drivers. Appl Psychol 1991;76:658-63.

31. Mulders HP, Meijman TF, O'Hanlon JF, Mulder G. Differential psychophysiological reactivity of city bus drivers. Ergonomics 1982;25:1003-11.

32. Paranosić M, Postić-Grujin A, Pajević D. Neki elementi vozačke sposobnosti pri noćnoj vožnji [Assessment of aspects of driver fitness during night driving]. Osijek: Institut za psihomedicinu saobraćaja 1980;10:79-83.

33. Kjeldsen SE, Rostrup M, Moan A, Mundal HH, Gjesdal K, Eide IK. The sympathetic nervous system may modulate the metabolic cardiovascular syndrome in essential hypertension. J Cardiovasc Pharmacol 1992;20 suppl 8:S532-9.

Received for publication: 12 June 1995 